\title{
Striving for optimal bronchodilation: focus on olodaterol
}

\author{
This article was published in the following Dove Press journal: \\ International Journal of COPD \\ I March 2016 \\ Number of times this article has been viewed
}

\section{Cristoforo Incorvaia' \\ Marcello Montagni² \\ Elena Makri' \\ Gian Galeazzo Riario- \\ Sforza' \\ Erminia Ridolo ${ }^{2}$}

'Allergy/Pulmonary Rehabilitation, Istituti Clinici di Perfezionamento Hospital, Milan, Italy; ${ }^{2}$ Department of Clinical and Experimental Medicine, University of Parma, Parma, Italy
Correspondence: Cristoforo Incorvaia Allergy/Pulmonary Rehabilitation, ICP Hospital, Via Bignami I, 20I26 Milan, Italy Tel +390257993289

Fax +39025799 3579

Email cristoforo.incorvaia@gmail.com
Abstract: $\beta_{2}$-agonists were introduced in the 1940 s as bronchodilators to be used in obstructive respiratory diseases. Long-acting $\beta_{2}$-agonists have been a mainstay of bronchodilating treatment for decades. Recently, agents extending their effect to 24 hours and thus allowing the once-daily administration were introduced, defined as very-long-acting $\beta_{2}$-agonists. Olodaterol is a new very-long-acting $\beta_{2}$-agonist that has been shown, in controlled trials, to improve lung function as well as clinical outcomes and quality of life. Most of these trials included patients with moderate, severe, or very severe chronic obstructive pulmonary disease (COPD). Olodaterol has a rapid onset of action (comparable to formoterol) and provides bronchodilation over 24 hours. In controlled trials, olodaterol was shown to be as effective as formoterol twice daily, but significantly superior in terms of quality of life in patients with COPD. The safety profile of olodaterol was very good, with a rate of adverse events, including the cardiac events that are particularly important for $\beta_{2}$-agonists, comparable to placebo. Also, the efficiency of the Respimat ${ }^{\circledR}$ device concurs to the effectiveness of treatment.

Keywords: bronchodilators, $\beta_{2}$-agonists, very long acting, olodaterol, efficacy, safety, COPD

\section{Introduction}

The first drugs aimed at obtaining bronchodilation in patients with asthma were aminophyllines in the $1940 \mathrm{~s} .{ }^{1}$ In the same years, drugs acting on the $\beta$-adrenoreceptor were developed, starting with isoproterenol and including in the following years salbutamol, orciprenaline, and terbutalin. ${ }^{2}$ Such drugs could be administered by injective, oral, and respiratory routes, but it was soon apparent that the safety and tolerability were significantly better with the respiratory route, especially regarding adverse effects on heart rate and blood pressure (that are due to stimulation of cardiac and vascular $\beta$-adrenoreceptors). ${ }^{3,4}$ The main limitation of these agents was the short duration of bronchodilation, defining them as short-acting $\beta_{2}$-agonists (SABAs) and requiring several inhalations each day with obvious problems of adherence. The next step was the development in the 1980 s of $\beta_{2}$-agonists with prolonged activity of bronchodilation, allowing two inhalations per day, such as salmeterol ${ }^{5}$ and formoterol. ${ }^{6}$ These drugs were defined as long-acting $\beta_{2}$-agonists (LABAs) and became a common treatment of asthma ${ }^{7}$ and chronic obstructive pulmonary disease (COPD) ${ }^{8}{ }^{89}$ From the 2000 s, a new generation of $\beta_{2}$-agonists is being developed, with a very prolonged bronchodilation that allows for once-daily dosing and makes them suitable for maintenance treatment of asthma and COPD. The first agent of this class demonstrating efficacy and safety was indacaterol. ${ }^{10}$ Because of its prolonged duration of action, a denomination of "ultraLABA" was proposed," but defining these drugs as "very-long-acting $\beta_{2}$-agonists (VLABAs)" seems to fit better with the usual nomenclature. ${ }^{12}$ Other VLABAs were 
recently introduced, such as vilanterol ${ }^{13}$ and olodaterol. ${ }^{14}$ As yet, vilanterol is available only in combination with the inhaled corticosteroid (ICS) fluticasone furoate ${ }^{15}$ and with the long-acting muscarinic antagonist (LAMA) umeclidinium, ${ }^{16}$ while olodaterol is available as single agent or in combination with the LAMA tiotropium, ${ }^{17}$ both administered by the device Respimat ${ }^{\circledR}$ Soft Mist ${ }^{\mathrm{TM}}$ inhaler (Boehringer Ingelheim, Ingelheim, Germany). ${ }^{18}$

Here, we review the literature on olodaterol to focus its possible role in the treatment of COPD.

\section{Pharmacological profile of olodaterol}

Olodaterol exerts its pharmacological effects by binding and activating $\beta_{2}$-adrenoceptors on human airway smooth muscle cells after topical administration by inhalation. Moreover, olodaterol is very highly selective for $\beta_{2}$ receptors as shown by in vitro studies that have detected that olodaterol has 241fold greater agonist activity at $\beta_{2}$-adrenoceptors compared to $\beta_{1}$-adrenoceptors. ${ }^{19}$ Activation of these receptors in the airways results in a stimulation of intracellular enzyme adenyl cyclase that mediates the synthesis of cyclic- $3^{\prime}, 5^{\prime}$ adenosine monophosphate (cAMP). Elevated levels of cAMP induce bronchodilation by relaxation of airway smooth muscle cells. ${ }^{20}$ Olodaterol also dose-dependently reversed the constriction induced by different stimuli, such as histamine and acetylcholine. ${ }^{19}$ In vivo, olodaterol showed a rapid onset of action (comparable to those obtained with formoterol) and provided bronchoprotection over 24 hours. In addition, anti-inflammatory effects of olodaterol were demonstrated in pulmonary fibroblasts in vitro, ${ }^{21}$ but the clinical significance of such an observation needs to be investigated in patients with obstructive respiratory disease.

\section{Characteristics of the inhalation device}

The Respimat ${ }^{\circledR}$ Soft Mist ${ }^{\mathrm{TM}}$ inhaler is a propellant-free inhaler based on a mechanical device generating a solution containing the drug with a smooth and slow aerosol cloud well-fitting with human inhalation. ${ }^{22}$ Most aerosol particle masses have a diameter of 1-5 $\mathrm{mm}$, with a high proportion belonging to the fine particle fraction, ie, with a diameter $<5.8 \mathrm{~mm}$, and this makes the penetration of the drug in the airways not strictly dependent on the patient's inspiratory effort. ${ }^{23}$ In fact, this inhaler deposits the drug more efficiently than dry powder inhalers (DPIs) or metered dose inhalers (MDIs), as showed by a lung deposition of budesonide significantly higher with Respimat ${ }^{\circledR}$ Soft Mist ${ }^{\mathrm{TM}}$ inhaler than with a DPI with fast flow rate, a DPI with slow flow rate, and an MDI. ${ }^{24}$ The first drug administered by Respimat ${ }^{\circledR}$ Soft Mist ${ }^{\mathrm{TM}}$ inhaler was tiotropium, which allowed a dose reduction from $18 \mu \mathrm{g}$ with the DPI HandiHaler to $5 \mu \mathrm{g}$ with the new device. In a recent review, in patients with COPD, tiotropium Respimat ${ }^{\circledR}$ improved lung function, COPD exacerbations, health-related quality of life, and dyspnea and showed an increase in efficacy and safety comparable to tiotropium HandiHaler ${ }^{\circledR}$ (Boehringer Ingelheim, Ingelheim, Germany), despite the dose reduction to less than one-third..$^{25}$

\section{Controlled trials on efficacy and safety of olodaterol}

The efficacy of olodaterol was shown by several large Phase III trials in terms of improvement in lung function as well as clinical outcomes and quality of life. Most of these trials included patients with moderate, severe, or very severe COPD, defined as a postbronchodilator forced expiratory volume in 1 second $\left(\mathrm{FEV}_{1}\right)<80 \%$ of the predicted value and a postbronchodilator $\mathrm{FEV}_{1}$ /forced vital capacity $<70 \%$ (Global initiative for chronic Obstructive Lung Disease [GOLD] 2-4). Also, the potential benefits of combined treatment with olodaterol and tiotropium (fixed dose administered via Respimat $^{\circledR}$ or administered separately with different device) were investigated. In a first single-center, double-blind, placebo-controlled, five-way crossover study, dose- and time-response, safety, and tolerability of once-daily dosing of $2,5,10$, and $20 \mu \mathrm{g}$ olodaterol was assessed in patients with COPD.${ }^{26}$ All doses of olodaterol provided significantly greater bronchodilation compared to placebo in 24-hour postdosing $\mathrm{FEV}_{1}$ (trough $\left.\mathrm{FEV}_{1}\right)(P<0.001)$ with a clear dose-response relationship. Moreover, olodaterol was superior to placebo $(P<0.001)$ in peak and average $\mathrm{FEV}_{1}$ both during the daytime ( $0-12$ hours) and nighttime (12-24 hours). Two replicate, randomized, double-blind, placebo-controlled, parallel-group, Phase III trials, including 624 and 642 patients, respectively, were then performed in order to investigate the long-term safety and efficacy of olodaterol delivered via the Respimat ${ }^{\circledR}$ inhaler in patients with moderate to very severe COPD.${ }^{27}$ In these trials, patients were randomized to receive olodaterol 5 or $10 \mu \mathrm{g}$ or placebo once daily for 48 weeks. $\mathrm{FEV}_{1}$ area under the curve from 0 to 3 hours $\left(\mathrm{AUC}_{0-3}\right)$ response (change from baseline) and trough $\mathrm{FEV}_{1}$ response were the primary end points of the studies, while secondary end points included additional lung function assessments, use of rescue medications, $\mathrm{FEV}_{1} \mathrm{AUC}_{0-12}$ response, and Patient Global Rating over 48 weeks. In both studies, olodaterol 5 and $10 \mu \mathrm{g}$ significantly improved the $\mathrm{FEV}_{1} \mathrm{AUC}_{0-3}$ response $(P<0.0001)$ 
and trough $\mathrm{FEV}_{1}(P<0.0001$ and $P<0.05)$ versus placebo, with an incidence of adverse events (AEs) in active groups that was comparable with that of placebo groups. Moreover, two more replicate, multicenter, randomized, double-blind, placebo-controlled, parallel-group, Phase III studies compared once-daily olodaterol via Respimat ${ }^{\circledR}$ device to placebo and also to twice-daily formoterol over 48 weeks in patients with moderate to very severe COPD. ${ }^{28}$ Both olodaterol and formoterol were significantly superior to placebo in terms of lung function improvement, but quality of life as assessed by the St George's Respiratory Questionnaire (SGRQ) total score was significantly improved versus placebo only with olodaterol and not with formoterol. The incidence of AEs was similar in olodaterol, formoterol, and placebo group; no abnormalities in vital signs, laboratory parameters, or electrocardiogram results were observed. Efficacy and safety of once-daily olodaterol $5 \mu \mathrm{g}$ (via Respimat ${ }^{\circledR}$ inhaler) combined with once-daily tiotropium $18 \mu \mathrm{g}$ (via HandiHaler ${ }^{\circledR}$ inhaler) versus once-daily tiotropium $18 \mu \mathrm{g}$ (via HandiHaler ${ }^{\circledR}$ ) combined with placebo (via Respimat ${ }^{\circledR}$ ) in patients with moderate to very severe COPD was evaluated in two controlled trials. ${ }^{29}$ The combined treatment of olodaterol + tiotropium resulted in significant improvements of lung function compared to tiotropium + placebo, and also showed significant improvements in SGRQ total scores, while the safety profile of the double therapy was comparable to that of tiotropium alone. Also, tiotropium + olodaterol fixed-dose combination $(2.5 / 5 \mu \mathrm{g}$ or $5 / 5 \mu \mathrm{g})$ was compared with the monocomponents (all treatments administered via Respimat ${ }^{\circledR}$ inhaler) over 52 weeks in patients with moderate to very severe COPD in two replicate, randomized, double-blind, parallel-group, multicentre, Phase III trials. ${ }^{30}$ Fixed-dose combination significantly improved $\mathrm{FEV}_{1} \mathrm{AUC}_{0-3}$ and trough $\mathrm{FEV}_{1}$ versus the monocomponents at either dose. Statistically significant improvements in SGRQ total score versus the monocomponents were only seen for tiotropium + olodaterol $5 / 5 \mu \mathrm{g}$. Again, the incidence of AEs was comparable between the fixed-dose combination and the monocomponents. A post hoc analysis of the results of these two trials revealed that olodaterol + tiotropium $5 / 5 \mu \mathrm{g}$ significantly improved $\mathrm{FEV}_{1}$ $\mathrm{AUC}_{0-3}$ and trough $\mathrm{FEV}_{1}$ in all GOLD severity groups compared to olodaterol $5 \mu \mathrm{g}$ and tiotropium $5 \mu \mathrm{g}$ alone, irrespective of whether patients had received prior LAMA or LABA maintenance treatment. ${ }^{31}$ An analysis of four randomized, double-blind, placebo-controlled, parallel-group, Phase III studies on 3,104 patients (see van Noord et $\mathrm{al}^{26}$ and Ferguson et $\mathrm{al}^{27}$ for the details of the trials) was conducted in order to evaluate the long-term safety of once-daily olodaterol in a large cohort of patients with moderate to very severe COPD; ${ }^{32}$ 876 patients received olodaterol $5 \mu \mathrm{g}, 883$ received olodaterol $10 \mu \mathrm{g}, 460$ received twice-daily formoterol $12 \mu \mathrm{g}$, and 885 received placebo. Overall incidence of on-treatment AEs, serious AEs, and deaths were balanced across treatment groups. Respiratory and cardiovascular AEs, including major adverse cardiac events, were reported at similar frequencies in placebo and all active treatment groups. Therefore, the safety profiles of both olodaterol 5 and $10 \mu \mathrm{g}$ delivered via Respimat $^{\circledR}$ were comparable to placebo and formoterol in this pooled analysis. More recently, a randomized Phase II study compared the bronchodilators profile of alternative dosing frequencies of two total daily doses of olodaterol (5 and $10 \mu \mathrm{g}$ ). ${ }^{33}$ Forty-seven patients were randomized to receive olodaterol $2 \mu \mathrm{g}$ twice daily, $5 \mu \mathrm{g}$ twice daily, $5 \mu \mathrm{g}$ once daily, and $10 \mu \mathrm{g}$ once daily in sequence over 3-week treatment periods. The efficacy of olodaterol $5 \mathrm{mg}$ once daily was superior, in terms of bronchodilatory profile, compared to $2 \mathrm{mg}$ twice daily; a similar degree of bronchodilation over 24 hours was found when once-daily $10 \mu \mathrm{g}$ and twice-daily $5 \mu \mathrm{g}$ dosing regimen were compared. Table 1 summarizes the main findings from controlled trials on olodaterol.

\section{The place of olodaterol in the treatment of COPD}

Bronchodilator drugs are indicated for the treatment of bronchial asthma and COPD. Currently, according to the recent guidelines on the two diseases, the indications to use bronchodilators are divergent. In fact, the updated Global Initiative for Asthma guidelines suggest to use only SABA as needed in the step of severity 1 and 2 (the latter requiring as controllers low-dose ICS or leukotriene receptor antagonists) and LABA in association with ICS at increasing doses in steps 3 and 4. The LABA tiotropium is suggested in step 4 in patients who are not well controlled. ${ }^{34}$ The dominant therapeutic role is sustained by ICS. Instead, the updated guidelines on COPD suggest SABA and short-acting muscarinic antagonists in the treatment of initial stages of the disease, while LABA, VLABA, and LAMA are suggested in more severe stages, with possible addition of theophylline or roflumilast in patients who are not well controlled. ICS is indicated only in patients with severe stage of COPD or with frequent exacerbations. ${ }^{35}$ This is due to the recent observation of an increased risk of pneumonia in COPD patients under regular treatment with ICS. ${ }^{36}$ Therefore, a reduced use of ICS is currently recommended, which is mirrored by an increased use of bronchodilators, based on prescription of both LABA and LAMA. The agents 


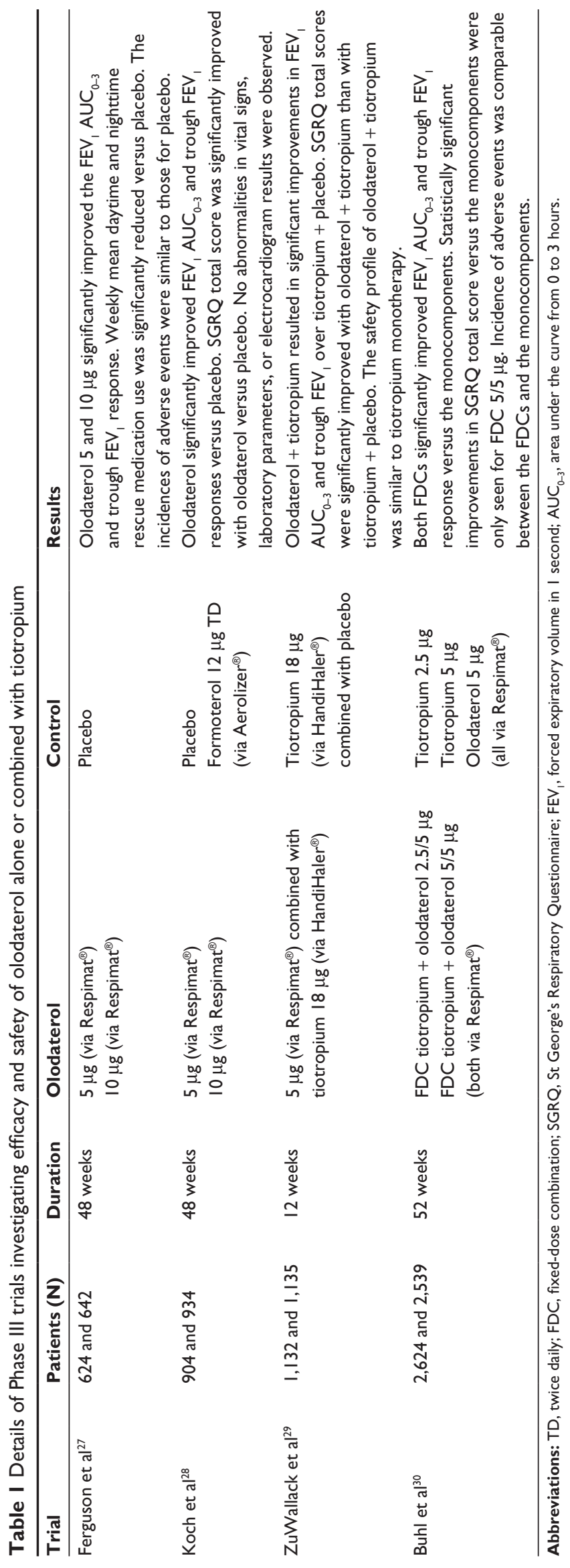

presently available are LABA (salmeterol and formoterol), VLABA (indacaterol, vilanterol, and olodaterol), ${ }^{37}$ and LAMA (tiotropium, glycopyrronium, umeclidinium, and aclidinium). Among LAMA, aclidinium requires twice-daily administration, while all the others can be administered once daily due to their 24-hour duration. ${ }^{38}$ In patients who need both LABA and LAMA because of insufficient benefit with a single bronchodilator, the treatment can be prescribed by combinations of drugs, with obvious advantages in terms of compliance and adherence. Fixed-dose combinations of indacaterol/glycopyrronium, ${ }^{39,40}$ umeclidinium/vilanterol, ${ }^{16}$ and olodaterol/tiotropium ${ }^{31}$ were developed. Indacaterol/ glycopyrronium is available in Europe but not in the US, while umeclidinium/vilanterol and olodaterol/tiotropium are available in both the US and Europe.

Concerning aclidinium, due to its twice-daily administration, the combination will include as LABA formoterol fumarate. ${ }^{41}$ All these drugs will be indicated for COPD, but considering the recommendations from the Global Initiative for Asthma guideline on the add-on therapy with LAMA (currently limited to tiotropium) in patients not controlled with ICS, LABA, and leukotriene receptor antagonist, it is reasonable to expect that an indication for other LAMAs in asthma will also follow. Analyzing the available drugs, VLABAs are likely to play a major role in the next years in consideration of the importance of patients' adherence. This issue concerns any chronic drug treatment, and of course also COPD.$^{42}$ Similar to other chronic diseases, such as arterial hypertension, the once-daily administration favors the patient's adherence. Among the VLABAs to be used once daily, vilanterol was evaluated thus far only in combination with fluticasone or umeclidinium, while products based only on VLABAs are available for indacaterol and olodaterol. No trials directly comparing the two drugs have been conducted thus far, although Roskell et al ${ }^{43}$ performed an indirect treatment comparison by systematic review and synthesis of the available clinical evidence. The outcomes analyzed were trough $\mathrm{FEV}_{1}$, transition dyspnea index, SGRQ total score, rescue medication use, and proportion of patients with exacerbations; data being obtained from 18 trials (ten with indacaterol and eight with olodaterol). Of note, olodaterol trials included patients of all severities, while indacaterol trials excluded patients with very severe COPD; concomitant maintenance bronchodilator use was allowed in most olodaterol trials, but not in indacaterol trials. In sensitivity analyses of the full network, results concerning the change from baseline in trough $\mathrm{FEV}_{1}$ favored indacaterol, but these data suffered from trial design heterogeneity. For the other 
end points investigated, no statistically significant differences were found when analyzed in the full network. The authors concluded that when compared under similar trial conditions, olodaterol and indacaterol have similar efficacy in patients with COPD. Still, the faster onset of bronchodilation with olodaterol, as assessed by a significant $\mathrm{FEV}_{1}$ increase versus placebo within 15 minutes for olodaterol but not for indacaterol, ${ }^{44}$ deserves to be clinically investigated. A factor concurring to the clinical effectiveness of olodaterol is the Respimat $^{\circledR}$ inhaler, that allows a propellant-free, smooth, and slow aerosol cloud well-fitting with inhalation in COPD patients, which often is impaired. In fact, this inhaler deposits the drug more efficiently than DPI or MDI, and this is clearly indicated by the significant dose reduction of the dose to be used with tiotropium by Respimat ${ }^{\circledR}$ compared with the dose administered by the DPI Handihaler ${ }^{\circledR}(18-5 \mu \mathrm{g})$.

\section{Conclusion}

Olodaterol fulfills the requirements for a complete bronchodilator drug to be used in obstructive respiratory diseases concerning efficacy and safety. In fact, it has a rapid onset of action, comparable to formoterol, and provides bronchodilation over 24 hours. This is distinctive of the recently developed new class of VLABA, that also includes indacaterol and vilanterol. The safety profile of olodaterol, as evaluated in the trials performed thus far, was shown to be very good, with a rate of AEs, including the cardiac events that are particularly important for $\beta_{2}$-agonists, comparable to placebo. ${ }^{27,28}$

\section{Disclosure}

The authors report no conflicts of interest in this work.

\section{References}

1. Prigal SJ, Fuchs AM, Schulman PM. The treatment of asthma with rectal suppositories of aminophylline and sodium pentobarbital. J Allergy. 1946;17:172-177.

2. Jack D. An introduction to salbutamol and other modern $\beta$-adrenoreceptors stimulants. Postgrad Med J. 1971;47(Suppl):8-11.

3. Johnsson G, Svedmyr N, Thiringer G. Effect of intravenous propranolol and metoprolol and their interaction on pulmonary function, heart rate and blood pressure in asthmatics. Eur J Clin Pharmacol. 1975;8(4): 175-180.

4. Minette A. Ventilatory results and side-effects of salbutamol given by different routes in coalminers with reversible broncho-obstruction. Postgrad Med J. 1971;47(Suppl):55-61.

5. Ullman A, Svedmyr N. Salmeterol, a new long acting inhaled $\beta_{2}$ adrenoceptor agonist: comparison with salbutamol in adult asthmatic patients. Thorax. 1988;43(9):674-678.

6. Becker AB, Simons FE. Formoterol, a new long-acting $\beta_{2}$-adrenergic receptors agonist: double-blind comparison with salbutamol and placebo in children with asthma. J Allergy Clin Immunol. 1989;84(6): 891-895.

7. Löfdahl CG, Chung KF. Long-acting $\beta_{2}$-adrenoceptor agonists: a new perspective in the treatment of asthma. Eur Respir J. 1991;4(2): 218-226.
8. Cazzola M, Spina D, Matera MG. The use of bronchodilators in stable chronic obstructive pulmonary disease. Pulm Pharmacol Ther. 1997;10(3): 129-144.

9. Santus P, Radovanocic D, Paggiaro P, et al. Why use long acting bronchodilators in chronic obstructive lung diseases? An extensive review on formoterol and salmeterol. Eur J Intern Med. 2015;26(6):379-384.

10. Beier J, Chanez P, Martinot JB, et al. Safety, tolerability and efficacy of indacaterol, a novel once-daily $\beta(2)$-agonist, in patients with COPD: a 28-day randomised, placebo-controlled clinical trial. Pulm Pharmacol Ther. 2007;20(6):740-749.

11. Vogelmeier C, Magnussen H, LaForce C, Owen R, Kramer B. Profiling the bronchodilator effect of the novel ultra-long-acting $\beta_{2}$-agonist indacaterol against established treatments in chronic obstructive pulmonary disease. Ther Adv Respir Dis. 2011;5(5):345-357.

12. Ridolo E, Montagni M, Olivieri E, et al. Role of indacaterol and the newer very long acting $\beta_{2}$-agonists in patients with stable COPD: a review. Int J Chron Obstruct Pulmon Dis. 2013;7:425-432.

13. Slack RJ, Barret VJ, Morrison VS, et al. In vitro pharmacological characterization of vilanterol, a novel long-acting-adrenoceptor agonist with 24-hour duration of action. J Pharmacol Exp Ther. 2013;344(1): 218-230.

14. Gibb A, Yang LP. Olodaterol: first global approval. Drugs. 2013;73(16): 1841-1846.

15. O'Byrne PM, Bleecker ER, Bateman ED, et al. Once-daily fluticasone furoate alone or combined with vilanterol in persistent asthma. Eur Respir J. 2012;43(3):773-782.

16. Blair HA, Deeks ED. Umeclidinium/vilanterol: a review of its use as maintenance therapy in adults with chronic obstructive pulmonary disease. Drugs. 2015;75(1):61-74.

17. Spina D. Current and novel bronchodilators in respiratory disease. Curr Opin Pulm Med. 2014;20(1):73-86.

18. Keating GM. Tiotropium Respimat ${ }^{\circledR}$ Soft Mist ${ }^{\mathrm{TM}}$ inhaler: a review of its use in chronic obstructive pulmonary disease. Drugs. 2014;74(15): 1801-1816.

19. Bouyssou T, Casarosa P, Naline E, et al. Pharmacological characterization of olodaterol, a novel inhaled $\beta_{2}$-adrenoceptor agonist exerting a 24-hour-long duration of action in preclinical models. $J$ Pharmacol Exp Ther. 2010;334(1):53-62.

20. Cazzola M, Page CP, Rogliani $P$, et al. $\beta_{2}$-agonist therapy in lung disease. Am J Respir Crit Care Med. 2013;187(7):690-696.

21. Costa L, Roth M, Miglino N, et al. Tiotropium sustains the antiinflammatory action of olodaterol via the cyclic AMP pathway. Pulm Pharmacol Ther. 2014;27(1):29-37.

22. Dalby L, Spallek M, Voshaar T. A review of the development of Respimat ${ }^{\circledR}$ Soft Mist ${ }^{\mathrm{TM}}$ Inhaler. Int J Pharm. 2004;283(1):1-9.

23. Hochrainer D, Holz H, Kreher C, et al. Comparison of the aerosol velocity and spray duration of Respimat ${ }^{\circledR}$ Soft Mist ${ }^{\mathrm{TM}}$ inhaler and pressurized metered dose inhalers. J Aerosol Med. 2005;18(3):273-282.

24. Pitcairn G, Reader S, Pavia D, et al. Deposition of corticosteroid aerosol in the human lung by Respimat ${ }^{\circledR}$ Soft Mist ${ }^{\mathrm{TM}}$ inhaler compared with deposition by metered dose inhaler or by Turbuhaler ${ }^{\circledR}$ dry powder inhaler. J Aerosol Med. 2005;18(3):264-272.

25. Bateman E, Singh D, Smith D, et al. Efficacy and safety of tiotropium Respimat ${ }^{\circledR} \mathrm{SMI}$ in $\mathrm{COPD}$ in two 1-year randomized studies. Int JChron Obstruct Pulmon Dis. 2010;5:197-208.

26. van Noord JA, Smeets JJ, Drenth BM, et al. 24-hour bronchodilation following a single dose of the novel $\beta(2)$-agonist olodaterol in COPD. Pulm Pharmacol Ther. 2011;24(6):666-672.

27. Ferguson GT, Feldman GJ, Hofbauer P, et al. Efficacy and safety of olodaterol once daily delivered via Respimat ${ }^{\circledR}$ in patients with GOLD 2-4 COPD: results from two replicate 48-week studies. Int J Chron Obstruct Pulmon Dis. 2014;9:629-645.

28. Koch A, Pizzichini E, Hamilton A, et al. Lung function efficacy and symptomatic benefit of olodaterol once daily delivered via Respimat ${ }^{\circledR}$ versus placebo and formoterol twice daily in patients with GOLD 2-4 COPD: results from two replicate 48-week studies. Int J Chron Obstruct Pulmon Dis. 2014;9:697-714. 
29. ZuWallack R, Allen L, Hernandez G, et al. Efficacy and safety of combining olodaterol Respimat ${ }^{\circledR}$ and tiotropium HandiHaler ${ }^{\circledR}$ in patients with COPD: results of two randomized, double-blind, active-controlled studies. Int J Chron Obstruct Pulmon Dis. 2014;9:1133-1144.

30. Buhl R, Maltais F, Abrahams R, et al. Tiotropium and olodaterol fixeddose combination versus mono-components in COPD (GOLD 2-4). Eur Respir J. 2015;45(4):969-979.

31. Ferguson GT, Fležar M, Korn S, et al. Efficacy of tiotropium + olodaterol in patients with chronic obstructive pulmonary disease by initial disease severity and treatment intensity: a post hoc analysis. Adv Ther. 2015; 32(6):523-536.

32. McGarvey L, Niewoehner D, Magder S, et al. One-year safety of olodaterol once daily via Respimat ${ }^{\circledR}$ in patients with GOLD 2-4 chronic obstructive pulmonary disease: results of a pre-specified pooled analysis. COPD. 2015;12(5):484-493.

33. Joos GF, Aumann JL, Coeck C, et al. A randomised, double-blind, four-way, crossover trial comparing the 24-hours FEV1 profile for oncedaily versus twice-daily treatment with olodaterol, a novel long-acting $\beta_{2}$-agonist, in patients with chronic obstructive pulmonary disease. Respir Med. 2015;109(5):606-615.

34. Global Initiative for Asthma. [homepage on Internet]. Available from: www.ginasthma.org. Accessed August 13, 2015.

35. Global Initiative for Chronic Obstructive Lung Disease. [homepage on Internet]. Available from: www.goldcopd.org. Accessed August 13, 2015.

36. Festic E, Scanlon PD. Incident pneumonia and mortality in patients with chronic obstructive pulmonary disease. A double effect of inhaled corticosteroids? Am J Respir Crit Care Med. 2015;191:141-148.
37. Spina D. Current and novel bronchodilators in respiratory disease. Curr Opin Pulm Med. 2014;20(1):73-86.

38. Montuschi P, Ciabattoni G. Bronchodilating drugs for chronic obstructive pulmonary disease: current status and future perspective. $J$ Med Chem. 2015;58(10):4131-4164.

39. Matera MG, Rogliani P, Cazzola M. QVA149 (indacaterol/ glycopirronium) for the treatment of chronic obstructive pulmonary disease. Expert Opin Pharmacother. 2015;16(7):1079-1090.

40. Ridolo E, Montagni M, Riario-Sforza GG, et al. Combination therapy with indacaterol and glycopyrronium bromide in the management of COPD: an update on the evidence for efficacy and safety. Ther $A d v$ Respir Dis. 2015;9(2):49-55.

41. Babu KS, Morjaria JB. Clinico-pharmacological profile of the fixed dose combination of aclidinium bromide and formoterol fumarate in the management of chronic obstructive pulmonary disease. Ther $A d v$ Respir Dis. 2015;9(2):56-68.

42. van Boven JF, Stuurman-Bieze AG, Hiddink EG, et al. Medication monitoring and optimization: a targeted pharmacist program for effective and cost-effective improvement of chronic therapy adherence. J Manag Care Spec Pharm. 2014;20(8):786-792.

43. Roskell NS, Anzueto A, Hamilton, et al. Once-daily long-acting $\beta$-agonists for chronic obstructive pulmonary disease: an indirect comparison of olodaterol and indacaterol. Int J Chron Obstruct Pulmon Dis. 2014;9:813-824.

44. Cazzola M, Beeh KM, Price D, et al. Assessing the clinical value of fast onset and sustained duration of action of long-acting bronchodilators for COPD. Pulm Pharmacol Ther. 2015;31:68-78.
International Journal of COPD

\section{Publish your work in this journal}

The International Journal of COPD is an international, peer-reviewed journal of therapeutics and pharmacology focusing on concise rapid reporting of clinical studies and reviews in COPD. Special focus is given to the pathophysiological processes underlying the disease, intervention programs, patient focused education, and self management protocols.

\section{Dovepress}

This journal is indexed on PubMed Central, MedLine and CAS. The manuscript management system is completely online and includes a very quick and fair peer-review system, which is all easy to use. Visit http://www.dovepress.com/testimonials.php to read real quotes from published authors. 